\title{
RENAL PLASMA FLOW AND SODIUM REABSORPTION AND EXCRETION IN CONGESTIVE HEART FAILURE ${ }^{1}$
}

\author{
By REUBEN MOKOTOFF,2 GEORGE ROSS, AND LOUIS LEITER \\ (From the Medical Division, Montefiore Hospital, New York City)
}

(Received for publication June 11, 1947)

Warren and Stead's (1) contention that disturbed renal function secondary to a diminished cardiac output is responsible for the following series of events-salt and water retention, increased blood and extracellular fluid volume, rise in venous pressure, edema-seemed to offer a rational explanation for some of the clinically observed phenomena. We therefore initiated a series of studies on patients with chronic congestive heart failure, using the clearance techniques of Smith and associates (2), in order to evaluate the relationship between the decreased sodium excretion in heart failure $(3,4)$ and renal blood flow, to determine the nature of the disturbance in renal function and the relationship, if any, between the altered renal dynamics and sodium retention. We later attempted to define some of the variables involved in the tubular transfer system for sodium as it obtains in the normal and in the cardiac patient. Since our studies began, Merrill (5) reported that the renal plasma flow was reduced to as little as 20 per cent and the filtration rate to 33 per cent of normal in chronic congestive failure. We have been able to confirm his findings of a decreased sodium excretion rate due to a diminished load presented to the tubules for reabsorption, and not to enhanced tubular reabsorption as suggested by earlier workers (3).

\section{EXPERIMENTAL PROCEDURE}

Patients with advanced chronic congestive failure due predominantly to rheumatic heart disease were the subjects. All had variable amounts of edema at rest. Members of the resident house staff and patients without heart failure or renal disease served as controls.

The subjects were brought to the laboratory in a postabsorptive state. Each patient was given 300 to $600 \mathrm{cc}$. of water about 30 to 60 minutes before the test period.

1 This study was aided by a grant from the Martha $M$. Hall Foundation and the Committee on Scientific Research of the American Medical Association.

2 Martha M. Hall Foundation Fellow in Medicine.
Five controls were maintained on a special cardiac saltpoor diet (about 1.3 grams of sodium chloride daily), for 4 to 5 days before the studies were made. Most of the patients with congestive heart failure were maintained on the same diet (strict metabolic control was not attempted) and, in addition, all were taking digitalis. Except for 1 cardiac who, by error, received mercupurin 48 hours before the test period, none had received mercurials or other diuretics for at least 72 hours prior to the clearance studies.

The effective renal plasma flow was measured with sodium para-aminohippurate ${ }^{8}$ and the glomerular filtration rate with mannitol, as recommended by the New York University group $(6,7)$. Priming solutions contained 55 to $80 \mathrm{cc}$. of 25 per cent mannitol and 2 to $5 \mathrm{cc}$. of 20 per cent para-aminohippurate, depending on the estimated size of the extracellular fluid compartment. Sustaining solutions were given at the rate of $4 \mathrm{cc}$. per minute and consisted of 4 to 5 per cent mannitol and 0.10 to 0.25 per cent para-aminohippurate made up in distilled water instead of saline. In 2 experiments, 4 per cent saline was used as the diluent. Three or more 20to 30-minute urine collection periods were carried out with an inlying 6-holed catheter, the bladder being washed out with 10 to 20 cc. distilled water. Venous blood samples were obtained at the beginning and end of each urine collection period and the concentration of the various substrates were plotted on semilogarithmic paper against time. Under our test conditions, the plasma mannitol concentration curve usually had a rising slope and the para-aminohippurate curve a falling slope. The mean concentration was obtained by interpolation to the middle of each period. The data for the clearance values are the averages for the 3 or more collection periods. They are all corrected to a body surface area of $1.73 \mathrm{sq} . \mathrm{m}$. We have used the body surface estimated from the weight which is ideal for a subject of given height, age, and sex rather than the actual surface estimated from the height and weight at the time of observation (8). In several instances, there was an appreciable correction factor in spite of edema because many of these patients had lost considerable body tissue secondary to their long-standing congestive failure. Had these correction factors not been applied, many of the clearance values would have been appreciably lower than are here reported. The chemical methods used are described in detail by Smith et al. (6) and Goldring and Chasis (9).

${ }^{8}$ Liberal quantities of sodium para-aminohippurate and mannitol were supplied by Dr. J. Wm. Crosson of Sharpe and Dohme. 
TABLE I

Summary of data

A. Patients with congestive failure

\begin{tabular}{|c|c|c|c|c|c|c|c|c|c|c|c|c|c|}
\hline \multirow[b]{2}{*}{ Patient } & \multirow[b]{2}{*}{ Age } & \multirow[b]{2}{*}{ Sex } & \multirow[b]{2}{*}{$\begin{array}{c}\text { Venous } \\
\text { pressure }\end{array}$} & \multirow[b]{2}{*}{$\begin{array}{c}\text { Renal } \\
\text { plasma } \\
\text { flow }\end{array}$} & \multirow[b]{2}{*}{$\begin{array}{c}\text { Filtra- } \\
\text { tion } \\
\text { rate }\end{array}$} & \multirow[b]{2}{*}{$\begin{array}{l}\text { Filtra- } \\
\text { tion } \\
\text { fraction }\end{array}$} & \multirow[b]{2}{*}{$\begin{array}{l}\text { Urine } \\
\text { flow }\end{array}$} & \multirow[b]{2}{*}{$\begin{array}{c}\text { Hema- } \\
\text { tocrit }\end{array}$} & \multirow[b]{2}{*}{$\begin{array}{c}\text { Blood } \\
\text { volume }\end{array}$} & \multirow{2}{*}{$\begin{array}{c}\text { *Devia- } \\
\text { tion } \\
\text { from } \\
\text { pre-- } \\
\text { dicted } \\
\text { normal } \\
\text { volume }\end{array}$} & \multicolumn{3}{|c|}{ Plasma Protein } \\
\hline & & & & & & & & & & & Albumin & Globulin & $\begin{array}{l}\text { Total } \\
\text { circuu- } \\
\text { lating }\end{array}$ \\
\hline $\begin{array}{l}\text { E. F. } \\
\text { P. B. } \\
\text { A. G. } \\
\text { L. C. } \\
\text { R. D. } \\
\text { E. S. } \\
\text { I. F. } \\
\text { tH. Z. } \\
\text { S. O. } \\
\text { O. W. } \\
\text { A. M. } \\
\text { B. G. } \\
\text { E. G. } \\
\text { tS. L. } \\
\text { †G. B. } \\
\text { W. S. }\end{array}$ & $\begin{array}{l}37 \\
23 \\
30 \\
16 \\
53 \\
56 \\
46 \\
23 \\
41 \\
37 \\
40 \\
24 \\
31 \\
46 \\
42 \\
40\end{array}$ & $\begin{array}{l}\text { M. } \\
\text { F. } \\
\text { F. } \\
\text { F. } \\
\text { M. } \\
\text { M. } \\
\text { F. } \\
\text { M. } \\
\text { F. } \\
\text { M. } \\
\text { F. } \\
\text { F. } \\
\text { F. } \\
\text { M. } \\
\text { M. }\end{array}$ & $\begin{array}{l}c m . \\
\text { water } \\
25 \\
26 \\
25 \\
11 \\
19 \\
20 \\
32 \\
20 \\
13.5 \\
18 \\
23 \\
25 \\
13 \\
30 \\
17 \\
24 \\
17 \\
10.5 \\
21\end{array}$ & $\begin{array}{l}c c . \text { per } \\
\text { p.73 } \\
166 \\
235 \\
225 \\
225 \\
181 \\
266 \\
253 \\
129 \\
218 \\
138 \\
172 \\
138 \\
150 \\
175 \\
175 \\
106 \\
180 \\
315 \\
188\end{array}$ & $\begin{array}{c}\text { in. per } \\
\text { q.m. } \\
52 \\
76 \\
82 \\
58 \\
66 \\
81 \\
83 \\
54 \\
65 \\
82 \\
60 \\
54 \\
58 \\
71 \\
74 \\
70 \\
32 \\
86 \\
66\end{array}$ & $\begin{array}{c}\text { per cent } \\
31.3 \\
32.3 \\
36.5 \\
25.8 \\
36.5 \\
30.4 \\
32.8 \\
41.8 \\
29.8 \\
59.4 \\
34.9 \\
39.1 \\
38.7 \\
40.6 \\
42.3 \\
66.0 \\
17.8 \\
27.3 \\
35.1\end{array}$ & $\begin{array}{c}c c . \\
p \text { per } \\
\text { min. } \\
1.2 \\
2.2 \\
2.6 \\
2.4 \\
2.1 \\
3.0 \\
1.6 \\
1.4 \\
2.3 \\
2.0 \\
2.1 \\
2.3 \\
3.1 \\
2.7 \\
2.9 \\
1.6 \\
1.6 \\
3.4 \\
3.8\end{array}$ & $\begin{array}{c}\text { per } \\
\text { pent } \\
\text { cells } \\
32.3 \\
35.7 \\
41.6 \\
30.9 \\
34.6 \\
38.1 \\
36.0 \\
45.0 \\
38.3 \\
43.1 \\
40.0 \\
39.6 \\
43.2 \\
42.6 \\
45.0 \\
43.1 \\
46.1 \\
51.0 \\
54.5\end{array}$ & $\begin{array}{c}c c . \\
7020 \\
6090 \\
7050 \\
5900 \\
7220 \\
3950 \\
7160 \\
9050 \\
3440 \\
6700 \\
4730 \\
5040 \\
5380 \\
4350 \\
6530 \\
7400 \\
5370 \\
6260 \\
6930\end{array}$ & $\begin{array}{l}\text { per cent } \\
+35 \\
+52 \\
+76 \\
+47 \\
+40 \\
+8 \\
+28 \\
+74 \\
8 \\
+13 \\
+17 \\
+40 \\
+2.0 \\
+21 \\
+70 \\
+95 \\
+68 \\
+12 \\
+24\end{array}$ & $\begin{array}{c}\text { grams } \\
\text { per } \\
\text { cent } \\
3.6 \\
5.0 \\
4.8 \\
5.7 \\
5.1 \\
4.8 \\
4.9 \\
3.8 \\
4.7 \\
3.7 \\
2.9 \\
3.9 \\
5.3 \\
4.4 \\
3.6 \\
2.5 \\
4.7 \\
3.9\end{array}$ & $\begin{array}{c}\text { grams } \\
\text { per } \\
\text { cent } \\
2.9 \\
3.3 \\
3.3 \\
3.1 \\
2.8 \\
2.4 \\
2.9 \\
2.8 \\
2.7 \\
2.2 \\
4.7 \\
4.0 \\
3.6 \\
2.7 \\
2.5 \\
1.4 \\
1.5 \\
1.6\end{array}$ & $\begin{array}{c}\text { grams } \\
308 \\
324 \\
334 \\
358 \\
372 \\
176 \\
360 \\
328 \\
141 \\
225 \\
215 \\
232 \\
272 \\
177 \\
219 \\
164 \\
180 \\
173\end{array}$ \\
\hline & & & $\underset{\sigma}{\text { mean: }}$ & $\begin{array}{r}191.5 \\
54.4\end{array}$ & $\begin{array}{l}66.8 \\
13.2\end{array}$ & $\begin{array}{r}37.8 \\
9.9\end{array}$ & & & & & & & \\
\hline
\end{tabular}

B. Normal controls and cardiac patients without congestive failure

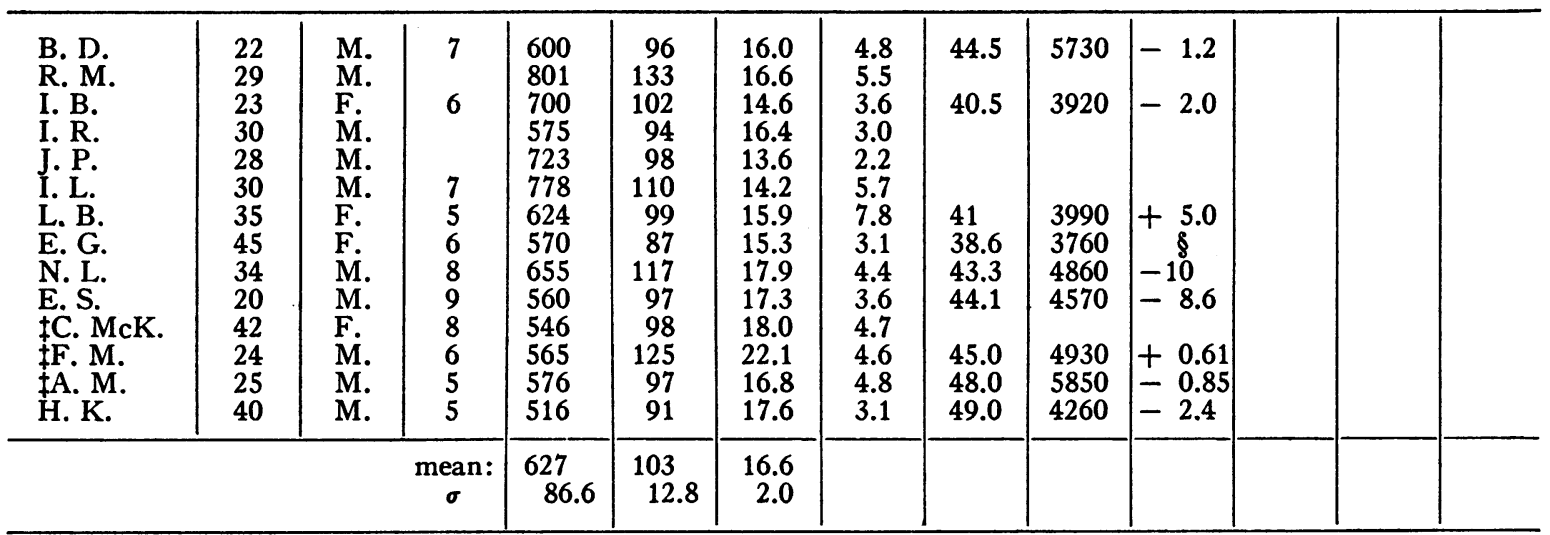

* Predicted blood volumes were based on height from the data of Gibson and Evans (15.).

† All the congestive failure patients had rheumatic heart disease except H. Z., S. L., and G. B., who had healed subacute bacterial endocarditis, amyloid heart disease, and hypertensive heart disease, respectively.

$\ddagger$ Non-failure cardiac patients.

Insufficient data for volume prediction on such short patients.

Sodium determinations were made by uranyl zinc acetate precipitation following a preliminary dry ashing of the sera and of the urine when the concentration of sodium in the latter was less than $0.1 \mathrm{mgm}$. per cc., as recommended by Butler and Tuthill (10). Total serum protein nitrogen was determined manometrically after the usual micro-Kjeldahl digestion (11). Albumin and glob- ulin separation was carried out according to the method described by Campbell and Hanna (12). Plasma volume was determined with the blue dye $\mathrm{T}-1824$, the optical density being measured with the photoelectric colorimeter. In preliminary experiments, we determined the plasma volumes in patients with congestive failure from extrapolation of a time-concentration curve and from a single 
TABLE II

Sodium clearance data; corrected to 1.73 sq. m.: average of 3 periods

A. Patients with congestive heart failure

\begin{tabular}{|c|c|c|c|c|c|c|c|}
\hline \multirow[b]{2}{*}{ Patient } & \multirow{2}{*}{$\begin{array}{c}\text { Glomerular } \\
\text { filtration } \\
\text { rate }\end{array}$} & \multicolumn{5}{|c|}{ Sodium } & \multirow{2}{*}{ Remarks } \\
\hline & & $\begin{array}{l}\text { Serum } \\
\text { conc. }\end{array}$ & Filtered* & Excreted & Reabsorbed & $\begin{array}{l}\text { Reabsorbed } \\
\text { per } 100 \mathrm{cc} \text {. } \\
\text { glomerular } \\
\text { filtrate }\end{array}$ & \\
\hline $\begin{array}{l}\text { E. F. } \\
\text { P. B. } \\
\text { A. G. } \\
\text { L. C. } \\
\text { R. D. } \\
\text { E. S. } \\
\text { I. F. } \\
\text { H. Z. } \\
\text { S. O. } \\
\text { O. W. } \\
\text { A. M. }\end{array}$ & $\begin{array}{cc}c c . / m i n . \\
52 \\
76 \\
82 \\
58 \\
66 \\
81 \\
83 \\
54 \\
65 \\
82 \\
60 \\
54 \\
58\end{array}$ & $\begin{array}{c}\boldsymbol{m} M / L . \\
131 \\
150 \\
137 \\
135 \\
137 \\
139 \\
124 \\
132 \\
129 \\
134 \\
136 \\
133 \\
129\end{array}$ & $\begin{array}{c}m M / \min . \\
6.81 \\
11.4 \\
11.2 \\
7.84 \\
9.04 \\
11.3 \\
10.3 \\
7.13 \\
8.39 \\
11.0 \\
8.16 \\
7.18 \\
7.48\end{array}$ & $\begin{array}{l}m M / m i n . \\
.0052 \\
.109 \\
.107 \\
.135 \\
.107 \\
.143 \\
.0026 \\
.0014 \\
.076 \\
.0052 \\
.0037 \\
.042 \\
.129\end{array}$ & $\begin{array}{c}m M / \min . \\
6.80 \\
11.3 \\
11.1 \\
7.70 \\
8.93 \\
11.2 \\
10.3 \\
7.13 \\
8.31 \\
11.0 \\
8.16 \\
7.14 \\
7.35\end{array}$ & $\begin{array}{l}m M \\
13.1 \\
14.9 \\
13.5 \\
13.3 \\
13.5 \\
13.8 \\
12.4 \\
13.2 \\
12.8 \\
13.4 \\
13.6 \\
13.2 \\
12.7\end{array}$ & $\begin{array}{l}\text { On regular diet } \\
\text { On regular diet } \\
\text { On regular diet } \\
\text { On regular diet } \\
\text { Mercupurin } 48 \text { hours before }\end{array}$ \\
\hline $\begin{array}{l}\text { B. G. } \\
\text { E. G. } \\
\text { S. L. }\end{array}$ & $\begin{array}{l}71 \\
70 \\
74 \\
32\end{array}$ & $\begin{array}{l}131 \\
139 \\
141 \\
137\end{array}$ & $\begin{array}{c}9.30 \\
9.74 \\
10.4 \\
4.38\end{array}$ & $\begin{array}{l}.010 \\
.0038 \\
.0091 \\
.085\end{array}$ & $\begin{array}{c}9.29 \\
9.74 \\
10.4 \\
4.29\end{array}$ & $\begin{array}{l}13.1 \\
13.9 \\
14.0 \\
13.4\end{array}$ & Infusion fluids contained 4 per \\
\hline $\begin{array}{l}\text { G. B. } \\
\text { W. S. }\end{array}$ & $\begin{array}{l}86 \\
66\end{array}$ & $\begin{array}{l}141 \\
135\end{array}$ & $\begin{array}{c}12.1 \\
8.91\end{array}$ & $\begin{array}{l}.090 \\
.0065\end{array}$ & $\begin{array}{c}12.0 \\
8.90\end{array}$ & $\begin{array}{l}14.0 \\
13.5\end{array}$ & \\
\hline
\end{tabular}

B. Normal controls and cardiac patients without congestive failure

\begin{tabular}{l|r|l|l|l|l|l|l} 
B. D. & 96 & 135 & 13.0 & .0416 & 13.0 & 13.5 & Low sodium diet \\
R. M. & 133 & 127 & 16.9 & .180 & 16.7 & 12.6 & \\
I. B. & 102 & 122 & 12.4 & .185 & 12.2 & 12.0 & \\
I. R. & 94 & 135 & 12.7 & .0853 & 12.6 & 13.4 & Low sodium diet \\
J. P. & 98 & 134 & 13.1 & .0610 & 13.0 & 13.3 & Low sodium diet \\
I. L. & 110 & 138 & 15.2 & .0808 & 15.1 & 13.7 & Low sodium diet \\
L. B. & 99 & 134 & 13.3 & .478 & 12.8 & 13.0 & Lodium diet \\
E. G. & 87 & 129 & 11.2 & .0788 & 11.1 & 12.8 & Low sodium \\
N. L. & 117 & 138 & 16.1 & .514 & 15.6 & 13.3 & Infusion fluids contained 4 per \\
& & & & & & & \\
E. S. & 97 & 142 & 13.8 & .365 & 13.4 & 13.8 & cent sodium chloride \\
C. McK. & 98 & 138 & 13.5 & .652 & 12.8 & 13.1 & \\
F. M. & 125 & 135 & 16.9 & .398 & 16.5 & 13.2 & \\
A. M. & 97 & 138 & 13.4 & .514 & 12.9 & 13.3 & \\
\end{tabular}

* The amount filtered is the product of the plasma concentration and the glomerular filtration rate (mannitol clearance). The amount excreted is the product of the urine concentration and the urine flow. The quantity reabsorbed is the difference between filtered and excreted amounts. See Table I for urine flow. period.

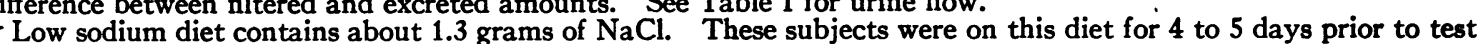

serum sample drawn 15 minutes after injection of the dye. The percentage error was 5 per cent or less. Therefore, in later experiments the single dye sample was used to determine the plasma volume using 10-minute samples (13) for normals and 15-minute samples for patients in congestive failure.

The venous pressure was measured with an L-shaped glass manometer filled with distilled water and heparin. The reference point was $5 \mathrm{~cm}$. below the fourth right costochondral junction, with the patient in the supine position.

\section{RESULTS}

Judging by the increased blood volume and elevated venous pressure, the degree of heart failure was moderate to severe (Table I). As was to be expected in a random group, with varying degrees of heart failure, there was no significant correlation between these 2 measurements. This was also found by Meneely and Kaltreider (14). A. M. was the only patient with a normal blood 


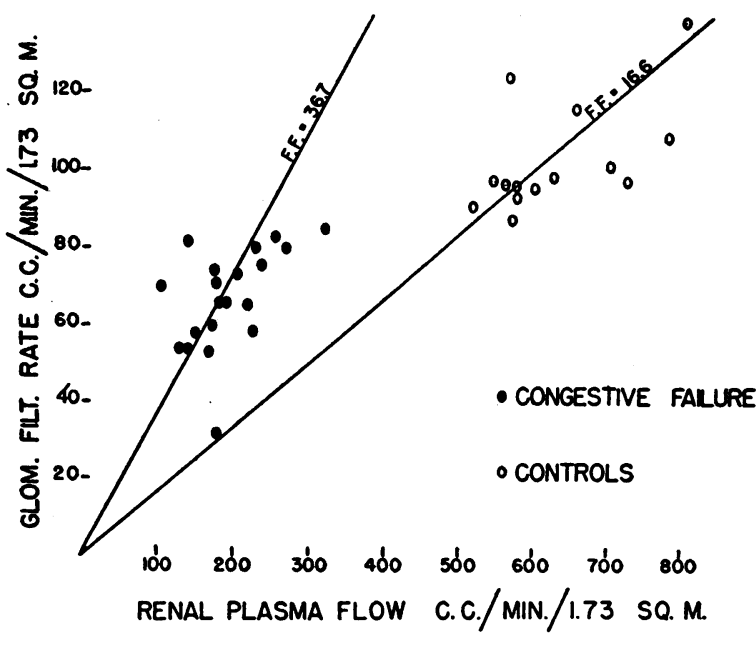

Fig. 1. The Glomerular Filtration Rate in Relation to Renal Plasma Flow in Controls and in Patients with Congestive Heart Failure

Each datum represents the average of at least 3 consecutive clearance periods. All patients are included in determining the mean values. The high filtration fraction in congestive heart failure is evident.

volume. This was his first attack of heart failure and he was studied when compensation was almost completely effected; also there was atrophy of the left arm and left leg due to an old hemiplegia.

The data pertaining to the clearance studies are given in Table $I$. The figures are the averages of 3 or more periods. It will be seen that the cardiac in congestive failure has a mean renal plasma flow of $191.5 \pm 54.4 \mathrm{cc}$. per minute as compared to a mean of $627 \pm 86.6 \mathrm{cc}$. per minute in our group of 14 non-failure control patients. The glomerular filtration rate was $66.8 \pm 13.2 \mathrm{cc}$. per minute in the cardiacs and $103 \pm 12.8$ cc. per minute in the controls. Thus, in congestive failure, the renal plasma flow is reduced on the average to approximately $1 / 3$ and the filtration rate to approximately $2 / 3$ of normal. The ratio of the mannitol and para-aminohippurate clearances or filtration fraction (FF), is considered to be a measure of the fraction of plasma filtered at the glomerulus. Our patients in heart failure have markedly elevated filtration fractions. If we omit 1 case, S. L., with a normal filtration fraction, who at necropsy had primary generalized amyloidosis including the myocardium and renal arterioles, the mean FF in the cardiacs was $37.8 \pm 9.9$ per cent. In our controls, which also included both sexes, FF had a mean value of $16.6 \pm 2.0$ per cent. The differences between the 2 groups are illustrated in Figure 1.

Table II summarizes the sodium clearance data. It is apparent that the patient's sodium intake prior to the test period influences the excretion rate, irrespective of the load that is filtered. Thus, 2 patients who were recovering cardiac compensation, A. G. and A. M., when placed on the routine ward diet (about 10 grams of $\mathrm{NaCl}$ ), excreted more than $0.1 \mathrm{mM}$ of sodium per minute, whereas 5 of the controls on a low sodium intake (about 1.3 grams of $\mathrm{NaCl}$ ) averaged $0.07 \mathrm{mM}$ per minute during the test period. However, most of the congestive failure patients on the same limited sodium intake had $1 / 2$ to $1 / 50$ the control excretion rates. The decreased sodium excretion of the congestive failure patient was also shown after intravenous infusion of 4 per cent saline given under similar conditions to both a cardiac in failure and to a control patient. The former excreted only $0.085 \mathrm{mM}$ per minute as compared to $0.514 \mathrm{mM}$ per minute for the control, or only about 17 per cent of the normal during the 90 minute observation period.

Despite the variations in the absolute quantities of sodium filtered, reabsorbed, and excreted in the 2 groups, a relatively constant fraction of the sodium in the glomerular filtrate is reabsorbed. This amounts to a mean of $13.3 \mathrm{mM}$ per $100 \mathrm{cc}$. of glomerular filtrate. Thus, while the cardiac in failure is delivering a smaller load of sodium to his tubules for excretion, his tubular capacity for sodium reabsorption is maintained. This is also illustrated in Figure 2, where it is evident that the rate of sodium reabsorption is a direct function of the glomerular filtration rate (mannitol clearance). It is interesting to note that this linear relationship between filtration rate and reabsorptive capacity has also been found by Pitts and Lotspeich $(16,17)$ to apply to the anions, bicarbonate and chloride. In their report, they raise the question and prove the point that "functional increases in filtration rate are accompanied by essentially equivalent increases in reabsorptive capacity." We have increased the filtration rate (Table III) in the normals from $100 \mathrm{cc}$. to $219 \mathrm{cc}$. maximally by infusing hypertonic sodium chloride 
solution ( 5 and 10 per cent), and in the cardiacs from 62 to $91 \mathrm{cc}$ : by the single intravenous injection of 0.72 gram of aminophyllin and/or $60 \mathrm{mgm}$. per minute in the infusion mixture. It was similarly found under our experimental conditions

TABLE III

Data illustrating the effect of altering the glomerular filtration rate upon the quantity of sodium reabsorbed

Experiment I was performed on the normal. Experiment II was performed on a patient in severe congestive heart failure. There is no correction for body surface.

\begin{tabular}{|c|c|c|c|c|c|c|}
\hline \multirow{2}{*}{$\begin{array}{c}\text { Glomer- } \\
\text { ular } \\
\text { filtra- } \\
\text { tion } \\
\text { rate }\end{array}$} & \multirow[b]{2}{*}{$\begin{array}{l}\text { Urine } \\
\text { flow }\end{array}$} & \multicolumn{5}{|c|}{ Sodium } \\
\hline & & $\begin{array}{c}\text { Plasma } \\
\text { conc. }\end{array}$ & Filtered* & Excreted & $\begin{array}{c}\text { Reab- } \\
\text { sorbed } t\end{array}$ & $\begin{array}{l}\text { Reabsorbed } \\
\text { per } 100 \text { cc. } \\
\text { glomerular } \\
\text { filtrate }\end{array}$ \\
\hline cc./min. & cc./min. & $m M / L$. & $\operatorname{mM} / \min$ & $m M / \min$. & $m M / \min$ & $m M$ \\
\hline
\end{tabular}

Experiment I

Infusion $\left\{\begin{array}{l}10 \text { per cent } \mathrm{NaCl} \\ 1.5 \text { per cent mannitol }\end{array}\right\} 10$ cc. per min.

\begin{tabular}{l|r|l|l|l|l|l}
\hline 143 & 7.1 & 153 & 20.8 & 0.983 & 19.8 & 13.8 \\
173 & 14.0 & 154 & 25.3 & 2.29 & 23.0 & 13.3 \\
176 & 18.5 & 159 & 26.6 & 3.01 & 23.6 & 13.4 \\
219 & 24.0 & 158 & 32.9 & 4.13 & 28.8 & 13.1 \\
\hline
\end{tabular}

$\mathrm{NaCl}$ infusion stopped

\begin{tabular}{l|r|l|l|l|l|l}
\hline 182 & 12.6 & 155 & 26.8 & 2.26 & 24.5 & 13.4 \\
151 & 12.8 & 155 & 22.2 & 2.33 & 19.9 & 13.2 \\
128 & 11.1 & 155 & 18.9 & 1.93 & 17.0 & 13.3 \\
119 & 8.9 & 154 & 17.4 & 1.55 & 15.9 & 13.3 \\
111 & 7.8 & 152 & 16.0 & 1.47 & 14.5 & 13.1 \\
102 & 5.9 & 149 & 14.4 & 1.15 & 13.3 & 13.0 \\
\hline
\end{tabular}

Experiment II

Infusion $\left\{\begin{array}{l}0.0 \text { per cent } \mathrm{NaCl} \\ 4 \text { per cent mannitol }\end{array}\right\} 4 c c$. per min.

\begin{tabular}{l|l|l|l|l|l|l}
\hline 69 & 1.78 & 140 & 9.16 & .00492 & 9.16 & 13.3 \\
62 & 1.53 & 138 & 8.13 & .00311 & 8.13 & 13.1 \\
63 & 1.48 & 139 & 8.32 & .00259 & 8.32 & 13.2 \\
\hline
\end{tabular}

Injection, 0.72 gram aminophyllin intravenously

\begin{tabular}{l|l|l|l|l|l|l}
\hline 91 & 3.76 & 142 & 12.3 & .0128 & 12.3 & 13.5 \\
89 & 4.56 & 142.5 & 12.1 & .0212 & 12.1 & 13.6 \\
90 & 4.78 & 141 & 12.1 & .0247 & 12.1 & 13.5 \\
\hline
\end{tabular}

* A constant of 0.95 was used to correct for the Donnan equilibrium.

t In patients with severe congestive failure, the amount of sodium excreted is insignificant in comparison to the filtered load. Hence, the reabsorbed and filtered quantities are identical. We have administered 4.8 per cent sodium chloride in combination with aminophyllin to such' patients and have found that the excreted amount of sodium increases to about 0.3 to $0.5 \mathrm{mM}$ per min. Under such circumstances, the amount reabsorbed per $100 \mathrm{cc}$. glomerular filtrate is greater than when sodium is not administered, but it is always less than the plasma sodium concentration.

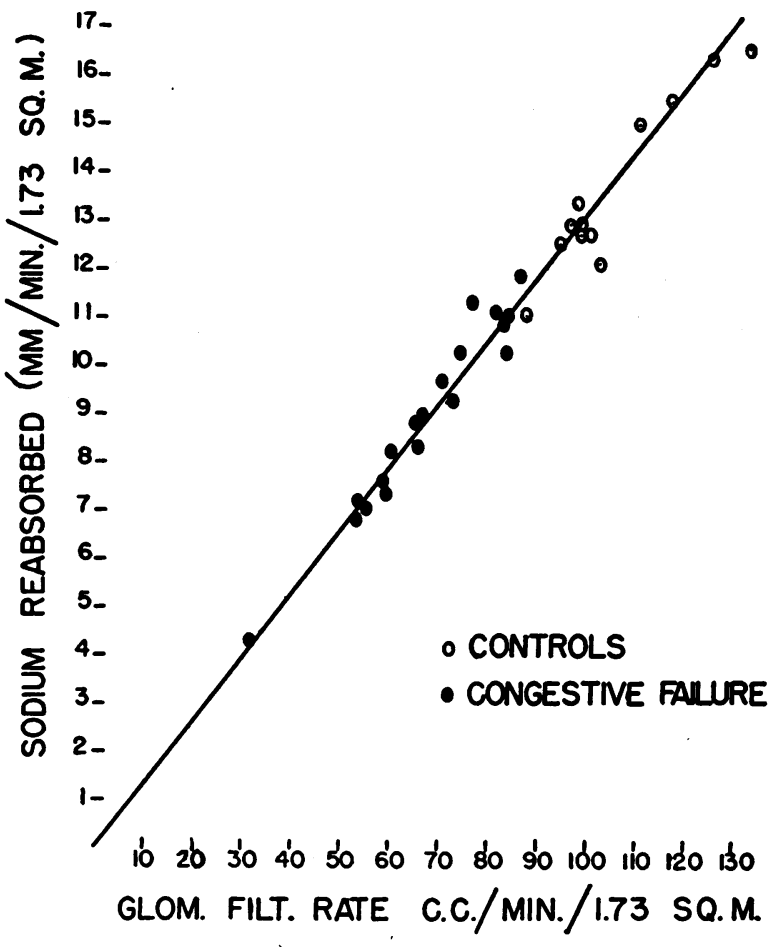

Fig. 2. The Linear Relationship between the Rate of Sodium REABSORPTION (MILLIMOLS PER MIN.) AND the Glomerular Filtration Rate (cc. per min.)

As in the previous figure each datum is the average of at least 3 clearance periods. The slope of the line is equivalent to $13.3 \mathrm{mM}$ of sodium reabsorbed per $100 \mathrm{cc}$. of glomerular filtrate. The sodium transfer mechanism in the tubule of the congestive failure patient is normal.

that functional increases in filtration rate are attended by proportional increases in tubular reabsorptive capacity. Hence, when the latter is expressed in millimols reabsorbed from each $100 \mathrm{cc}$. of glomerular filtrate, a constant quantity is obtained (Figure 3).

From the data in Table I, it is also apparent that there is no relationship between the venous pressure and the reduced renal plasma flow. The increase in total circulating proteins with a slight decrease in concentration due to hemodilution is the usual finding in congestive heart failure (18). Two of our cases, E. G. and S. O., had a low plasma albumin concentration, which we attribute to the deficient protein intake common in the later stages of congestive heart failure. The mean arterial pressure of our subjects was within the normal range. The reduced renal plasma flow was therefore not due to a decrease in driving 


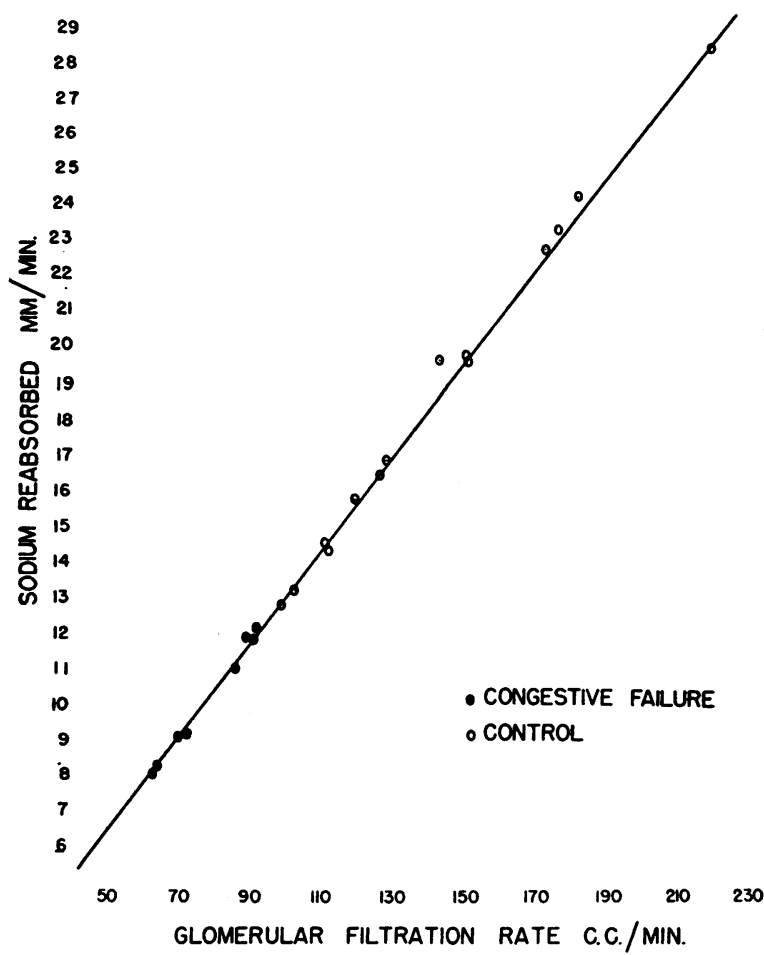

Fig. 3. Showing the Effect of Varying the Filtration Rate upon the Amount of Sodium ReabSORBED

The constancy of the fraction of sodium reabsorbed is maintained. The filtration rate in the normal (circles) was increased by venoclysis of hypertonic saline; in the cardiac (dots) by the intravenous injection of aminophyllin. Each datum is a single clearance period.

pressure but rather to an increased resistance to flow.

\section{DISCUSSION}

The question may be raised as to the validity of the renal clearance techniques in patients with congestive heart failure. Despite the variations in renal vasomotor activity and interstitial pressure in this condition, it has been shown (5) by renal vein catheterization that the extraction ratio of para-aminohippurate is within normal limits ; hence, its clearance at low plasma concentrations may be employed as a measure of "effective" renal plasma flow. Barker and Clarke (19) have recently demonstrated that the presence of paraaminohippurate in the specimens analyzed for mannitol results in an apparent increase in the hexitol. For every milligram of para-aminohippurate in the sample analyzed, there is an ap- parent increase of approximately $0.27 \mathrm{mgm}$. of mannitol when determined by the method (periodate-iodide-thiosulfate) employed in this study. Therefore, the glomerular filtration rates as reported in the controls are in error by approximately 2 per cent. It is somewhat smaller than this in our cardiacs, since the absolute amount of para-aminohippurate present was smaller because of the decreased blood flow. However, the relative decrease in the filtration rate in the cardiac, when compared to the normals, is unaltered by this correction.

It should be noted that the rate of sodium excretion for 24 hours must not be calculated from clearance data derived from 20- to 30-minute urine collection periods under experimental conditions. The absolute sodium intake, the glomerular filtration rate, and the effect of osmotically active solutes must be accounted for during the 24 hours. Thus, the concentration of mannitol in the urine varied from 3 to 6 per cent depending on the urine flow and, as expected from its action as an osmotic diuretic, increased the excretion of sodium from 1.2 to 2.2 times the amount in the control period without the use of mannitol. These variables help explain the persistence of edema in a patient such as P. B., who was excreting $0.11 \mathrm{mM}$ of sodium per minute during the experiment, or 3.64 grams of sodium if calculated for 24 hours.

From the data in the literature, it is estimated that normally 18 per cent, or approximately $1 / 5$ of the cardiac output, flows through the kidneys. We have calculated from Merrill's (5) data that the renal fraction of the cardiac output is reduced in heart failure to 7.4 per cent or about $2 / 5$ of normal. A similar shunting mechanism occurs in other varied conditions such as orthostasis, traumatic shock (20) and chronic anemia (21), in which the common denominator is a reduced "effective" circulating blood volume, and all of which are associated with a reduced renal plasma flow and filtration rate. However, these conditions, unlike chronic congestive heart failure, are commonly associated with a decreased filtration fraction. The homeostatic mechanism of diverting blood from the kidney when the cardiac output falls is unknown. The meager data available at present seem to support the theory of a neurogenic mechanism in the early stages of cardiac failure, later sustained by a chemical mediator (22). 
Since the fraction of plasma water filtered at the glomeraulus is greater in congestive heart failure than has been reported in other clinical states, signifying marked efferent arteriolar constriction and increased filtration pressure, we have attempted to calculate the intraglomerular pressure in one of our severe cases of failure. We believe the results are only an approximation but they furnish a hemodynamic description of the factors involved. We have drawn liberally from Smith's (23) descriptions. We believe the patient, E. G., was able to achieve a filtration fraction (FF) of 66 per cent because of the decreased oncotic pressure due to the low plasma albumin (2.5 grams per cent). We estimate (24) the initial oncotic pressure to be $13 \mathrm{~mm}$. $\mathrm{Hg}$. At filtration equilibrium, the plasma proteins will have become concentrated

$$
1+\frac{\mathrm{FF}}{1.0-\mathrm{FF}}
$$

or 2.94 times. The equilibrium oncotic pressure will now be 13 times 2.94 or $38.2 \mathrm{~mm}$. Hg. We have assumed the capsular pressure, or its equivalent, the interstitial pressure, to be about $20 \mathrm{~mm}$. Smith employs $15 \mathrm{~mm}$. for normal capsular pressure. We have used the larger figure because of the severe passive congestion. At equilibrium, the sum of the capsular and oncotic pressures will equal the intraglomerular hydrostatic pressure. We have, therefore, $58.2 \mathrm{~mm}$. $\mathrm{Hg}$ for the latter or about 72 per cent of the mean $(81 \mathrm{~mm}$.) systemic pressure, as compared to an intraglomerular pressure of about 50 per cent of the mean systemic pressure in the normal (23). This calculation assumes a mean normal extraction ratio.

The tubular reabsorptive mechanism which maintains the plasma concentration of sodium at a fairly constant level is dependent on the glomerular filtration rate. Thus, the amount of sodium filtered (millimols per minute) is given by the plasma concentration $\mathrm{P}_{\mathrm{Na}}$ ( $\mathrm{mM}$ per cc.) multiplied by the filtration rate $\mathrm{C}_{\mathbf{M}}$ (cc. per min.), or $\mathrm{P}_{\mathrm{Na}} \mathrm{C}_{\mathbf{M}},{ }^{4}$ and is equal to the sum of the reabsorbed and excreted amounts. In equation form,

$$
\mathrm{P}_{\mathrm{Na}} \mathrm{C}_{\mathrm{M}}=\mathrm{T}_{\mathrm{Na}}+\mathrm{U}_{\mathrm{Na}} \text {, }
$$

where $T_{\mathrm{Na}}$ is the rate of tubular reabsorption of

4 In more precise terms, the product should be written as $K \cdot P_{N a} \cdot C_{M}$, where $K$ is the Donnan equilibrium constant. sodium ( $\mathrm{mM}$ per min.) ; $\mathrm{U}_{\mathrm{Na}}$, the urine concentration of sodium ( $\mathrm{mM}$ per cc.) ; and $\mathrm{V}$, the urine flow (cc. per min.).

Dividing through by $\mathrm{C}_{M}$, we have

$$
\mathrm{P}_{\mathrm{Na}}=\frac{\mathrm{T}_{\mathrm{Na}}}{\mathrm{C}_{\mathrm{M}}}+\frac{\mathrm{U}_{\mathrm{Na}} \mathrm{V}}{\mathrm{C}_{\mathrm{M}}} .
$$

If the last term is omitted because it is minute under normal circumstances in comparison to the reabsorbed quantity of sodium, then the slope of the line obtained when $T_{N a}$ is plotted against $C_{M}$ represents $\mathrm{P}_{\mathrm{Na}}$, the plasma concentration. Under conditions of sodium administration when its excretion is increased, the second factor of Equation II is significant, under which circumstance the slope obtained represents the plasma concentration only as an approximation.

We have tried unsuccessfully on several occasions to demonstrate an overall limiting maximal capacity in the sodium transfer system by increasing the load presented to the tubules; in 1 instance the filtration rate reached a maximum of 219 cc. per minute and the plasma concentration of sodium was increased to $158 \mathrm{mM}$ per liter. At all times, a constant quantity of sodium per $100 \mathrm{cc}$. of glomerular filtrate was reabsorbed. This is similar to the transfer mechanism for bicarbonate and chloride $(16,17)$. This dependence of the rate of sodium reabsorption upon filtration rate remains unaltered in heart failure and we must conclude that the renal tubule in congestive failure functions normally in so far as the reabsorption of sodium is concerned.

It may be questioned whether peripheral venous pressure accurately reflects the magnitude of the renal venous pressure, and whether the diminished renal blood flow may be attributable to the elevated renal venous pressure. However, if one decreases the venous pressure (peripheral, atrial and renal, presumably) with the use of mercurial diuretics, the renal plasma flow is not altered significantly. The decreased renal plasma flow is correlated with the decreased cardiac output and not with the increased atrial pressure (5). By what intermediary mechanism an altered cardiac output reflects itself in an altered renal plasma flow and filtration rate remains to be elucidated.

We believe that some of the divergent views in the literature concerning the pathogenesis of cardiac edema could be reconciled if some of the vari- 
ables would be controlled at the onset of the study. The patients studied by Reichsman and Grant (25) have no blood volume determinations. It is known that in any closed elastic system which is near capacity, any further tendency to increase the volume of that system first produces an increase in pressure. This may help explain the increase in venous pressure which was seen before the weight gain in their studies. Their criticism that Warren and Stead's (1) patient may have been dehydrated and that the weight gain preceding the rise in venous pressure during congestive failure represented replacement of lost water and salt, is not justified in view of the fact that there wąs no fluid restriction and the patient's plasma volume was $58 \mathrm{cc}$. per $\mathrm{kgm}$. Landis and coworkers (26) have recently called attention to the fact that conclusions drawn from studies done under basal conditions, as in the present study, cannot be carried over in entirety to the cardiac with decreased "competence" only during activity. We agree that a rigid division between "backward failure" and "forward failure" is not consistent with all the facts. However, we are also of the opinion that salt and water retention leading to edema, secondary to a decreased glomerular filtration rate, is the major underlying factor in such diversified states as chronic congestive failure and chronic anemia. Edema would also occur in traumatic shock and orthostasis if these conditions were prolonged and normal sodium intake maintained. This sequence differs from the normal only in degree. Lyons and co-workers (27) have shown that when the normal subject ingests 40 grams of sodium chloride in 48 hours, there is a mean increase of plasma volume of 15.6 per cent and an increase of venous pressure of 31 per cent.

\section{SUMMARY}

1. The renal plasma flow and glomerular filtration rate were measured in patients with chronic congestive heart failure by the use of the paraaminohippurate and mannitol clearances. It was found that, on the average, the renal plasma flow is reduced to about $1 / 3$ and the filtration rate to $2 / 3$ of normal.

2. Under our experimental conditions, the renal tubules reabsorb a mean of $13.3 \mathrm{mM}$ of sodium from every 100 cc. of glomerular filtrate. Several patients, both cardiacs and normals, averaged somewhat higher than this mean value, while others somewhat lower. This mechanism operates in both normal man and in the patient with congestive heart failure. It offers an explanation for the relative stability of the blood sodium level.

3. In patients with congestive heart failure and in normals, physiologically induced variations in the glomerular filtration rate reveal constancy in the sodium reabsorptive mechanism.

4. The decreased excretion rate of sodium in congestive heart failure is attributable to a decreased filtration rate in the presence of normal tubular reabsorption.

We gratefully acknowledge helpful suggestions from Prof. H. W. Smith.

\section{BIBLIOGRAPHY}

1. Warren, J. V., and Stead, E. A., Jr., Fluid dynamics in chronic congestive heart failure; interpretation of mechanisms producing edema, increased plasma volume and elevated venous pressure in certain patients with prolonged congestive failure. Arch. Int. Med., 1944, 73, 138.

2. Smith, H. W., Goldring, W., and Chasis, H., The measurement of the tubular excretory mass, effective blood flow and filtration rate in the normal human kidney. J. Clin. Invest., 1938, 17, 263.

3. Futcher, P. H., and Schroeder, H. A., Studies on congestive heart failure; impaired renal excretion of sodium chloride. Am. J. M. Sc., 1942, 204, 52.

4. Reaser, P. B., and Burch, G. E., Radiosodium tracer studies in congestive heart failure. Proc. Soc. Exp. Biol. \& Med., 1946, 63, 543.

5. Merrill, A. J., Edema and decreased renal blood flow in patients with chronic congestive heart failure: evidence of "forward failure" as the primary cause of edema. J. Clin. Invest., 1946, 25, 389.

6. Smith, H. W., Finkelstein, N., Aliminosa, L., Crawford, B., and Graber, M., The renal clearances of substituted hippuric acid derivatives and other aromatic acids in dog and man. J. Clin. Invest., 1945, 24, 388.

7. Smith, W. W., Finkelstein, N., and Smith, H. W., Renal excretion of hexitols (sorbitol, mannitol and dulcitol) and their derivatives (sorbitan, isomannide and sorbide) and of endogenous creatininelike chromogen in dog and man. J. Biol. Chem., 1940, 135, 231.

8. McIntosh, J. F., Moller, E., and Van Slyke, D. D., Studies of urea excretion: the influence of body size on urea output. J. Clin. Invest., 1929, 6, 467. 
9. Goldring, W., and Chasis, H., Hypertension and $\mathrm{Hy}-$ pertensive Disease. Commonwealth Fund, New York, 1944, pp. 195-205.

10. Butler, A.M., and Tuthill, E., An application of the uranyl zinc acetate method for determination of sodium in biological material. J. Biol. Chem., 1931, 93, 171.

11. Peters, J. P., and Van Slyke, D. D., Quantitative Clinical Chemistry. The Williams \& Wilkins Company, Baltimore, 1932, Vol. II, p. 516.

12. Campbell, W. R., and Hanna, M. I., The albumin, globulins and fibrinogen of serum and plasma. $\mathrm{J}$. Biol. Chem., 1937, 119, 15.

13. Gregersen, M. I., A practical method for the determination of blood volume with the dye T-1824. J. Lab. \& Clin. Med., 1944, 29, 1266.

14. Meneely, G. R., and Kaltreider, N. L., A study of the volume of the blood in congestive heart failure. Relation to other measurements in fifteen patients. J. Clin. Invest., 1943, 22, 521.

15. Gibson, J. G., 2nd, and Evans, W. A., Jr., Clinical studies of the blood volume. II. The relation of plasma and total blood volume to venous pressure, blood velocity rate, physical measurements, age and sex in 90 normal humans. J. Clin. Invest., 1937, 16, 317.

16. Pitts, R. F., and Lotspeich, W. D., Bicarbonate and the renal regulation of acid base balance. Am. J. Physiol., 1946, 147, 138.

17. Lotspeich, W. D., Swan, R. C., and Pitts, R. F., The renal tubular reabsorption of chloride. Am. J. Physiol., 1947, 148, 445.

18. Seymour, W. B., Pritchard, W. H., Longley, L. P., and Hayman, J. M., Jr., Cardiac output, blood and interstitial fluid volumes, total circulating serum protein, and kidney function during cardiac failure and after improvement. J. Clin. Invest., 1942, 21, 229.

19. Barker, H. G., and Clark, J. K., Effect of paraaminohippurate on mannitol determinations by the periodate-iodide-thiosulfate method. Proc. Soc. Exp. Biol. \& Med., 1947, 64, 120.

20. Lauson, H. D., Bradley, S. E., and Cournand, A., The renal circulation in shock. J. Clin. Invest., 1944, 23, 381.

21. Bradley, S. E., and Bradley, G. P., Renal function during chronic anemia in man. Blood, 1947, 2, 192.

22. Merrill, A. J., Morrison, J. L., and Brannon, E. S., Concentration of renin in renal venous blood in patients with chronic heart failure. Am. J. Med., 1946, 1, 468.

23. Smith, H. W., Chasis, H., Goldring, W., and Ranges, H. A., Glomerular dynamics in the normal human kidney. J. Clin. Invest., 1940, 19, 751.

24. Wies, C. H., and Peters, J. P., The osmotic pressure of proteins in whole serum. J. Clin. Invest., 1937, $16,93$.

25. Reichsman, F., and Grant, H., Some observations on the pathogenesis of edema in cardiac failure. Am. Heart J., 1946, 32, 438.

26. Landis, E. M., Brown, E., Fauteux, M., and Wise, C., Central venous pressure in relation to cardiac "competence," blood volume and exercise. J. Clin. Invest., 1946, 25, 237.

27. Lyons, R. H., Sanders, J., and Johnston, F. D., Changes in the circulation with small changes in body fluid; preliminary report. Univ. Hosp. Bull., Ann Arbor, 1945, 11, 10. 